\title{
Assessment of highland rice varieties with high yielding and early maturing at Kerinci
}

\author{
Jon Hendri ${ }^{*}$ Endi Putra, and BS Busyra \\ Assesment Institute for Agricultural Technology of Jambi, Jl. Samarinda Paal Lima Kotabaru 36128 \\ Jambi, Indonesia
}

\begin{abstract}
Rice varieties with high production and early age in the highlands paddy fields have not much breeding results. Rice production is affected by low temperature and humidity. This study aimed to obtain high yielding and early maturing rice varieties among several varieties cultivated at Kerinci. This research was conducted on paddy fields in Kerinci Jambi district with an altitude of 800-950 meter above sea level. Time series were carried out from 2017, 2018, 2019 using the adaptive highland rice varieties Inpari 28 Kerinci, Sarinah, Inpari 30 and Inpari 32 cropping systems jajar legowo. The results showed that the Inpari 28 Kerinci variety had a production $7.46 \mathrm{tha}^{-}$ ${ }^{1}$ followed by Sarinah 6.83 then Inpari 30 as much as $6.47 \mathrm{t} \mathrm{ha}^{-1}$ and Inpari 32 as much as $6.17 \mathrm{t} \mathrm{ha}^{-1}$. Inpari 28 Kerinci variety and shorter maturity with a harvest age of 96-105 days after transplanting.
\end{abstract}

\section{Introduction}

Rice farmers face challenges like drying up of irrigation water sources, conversion of wetland to dryland due to developmental activities, paddy fields getting fallowed over time, multifold increase in wages and the younger generation not taking up farming. Rice is the most important crop in the world as more than half of the world's population depend on it as the staple food [1]. Data shows that eleven countries of Asia contribute about $87 \%$ of the global rice production and hence Asia significantly contributes in achieving global food security [2]. However, the rice sector is hit by many abiotic, biotic and socioeconomic constraints that hinder its production [3] Among biotic stresses, revealed that weather is the most important determinant of growth, yield and production of rice [4].

Rice sector is hit by challenges like drying out of irrigation water, unpredictable precipitation and, potential rice fields being fallowed - all attributed to climate change and global warming [5] Moreover limited wetland, use of low yielding traditional varieties, inadequate inorganic fertilizer inputs, insufficient irrigation water and labor shortage are the main factors leading to the low productivity of rice in Indonesia [6].

Highland is one of the potentials that can be used as an alternative effort for the development of rice paddy planting area. The area of highland land with a slope greater than $15 \%$ is estimated at 25.5 million hectares [7]. Of the area reportedly only 0.50 million hectares used for rice fields with an average rice yield ranging from 2.5-5.0 $\mathrm{t} \mathrm{ha}^{-1}$ [8]. In

* Corresponding author: djhonhend@gmail.com 
Jambi, especially Kerinci and Sungai Penuh district is a highland area with an altitude of 700$1500 \mathrm{~m}$ above sea level ( $\mathrm{m}$ asl), the area of rice planting based on BPS 2019 data is 22,886 hectares with a total production of 104,521 tons. from the area of rice fields Kerinci is a rice producing area with an area of no. 1 and a rice barn area with an average production of $5.6 \mathrm{t}$ ha $^{-1}$.

Use of appropriate and adaptive varieties is one of the approaches that can be done for highland rice fields in addition to land improvement by providing ameliorant materials and providing balanced fertilizer. New superior varieties are one of the main technologies that are able to increase crop productivity by $50-75 \%$, especially when followed by improved land quality by providing balanced ameliorant and fertilization materials.

Varieties of rice paddy for the highlands by the breeders are directed at the formation of low temperature tolerant rice plants, efficient in the utilization of water and sunlight, resistant to high humidity and pest-resistant diseases, so as to produce in a short time (short life) and has high yield potential. While the improvement of land quality is more directed at the provision of ameliorant materials and the provision of fertilizer in a balanced manner. Currently, new superior variety has been released by Indonesian Agency for Agricultural Research and Development. which has the advantage of each variety so that it is expected to be a consideration in the selection of varieties for consumers. This is important so that the loss of results can be minimized. Indonesian Agency for Agricultural Research and Development has released several superior varieties suitable for highland ecosystems $(>700$ $\mathrm{m}$ above sea level), namely Batang Piaman, Inpari 26, Inpari 27 and Inpari 28 Kerinci.

One of the strategies of rice development of highland rice is the available varieties of superior low temperature tolerant [9]. Rice fertilization in the highlands is generally at low doses. Therefore, superior varieties of highlands must be able to efficiently absorb nutrients in suffocating growth environment conditions. Highland rice breeding results in the form of adaptive superior varieties with low input and location specifics [10]. This study aim is to see the consistency of rice variety production in the highlands in Jambi.

\section{Methodology}

\subsection{Time and location}

This activity was carried out on highland rice fields in Kerinci Regency, Jambi Province located in the positions of $01^{\circ} 40$ 'and $02^{\circ} 26^{\prime}$ ' South Latitude, and $101^{\circ} 08$ 'to $10^{\circ} 50^{\prime}$ ' East Longitude. The Jambi Province is entirely south of the equator. The area of Kerinci Regency is $344,931 \mathrm{Ha}$ or $3,449.31 \mathrm{~km}^{2}$ with the height of the assessment site $800-950$ meter above sea level [11]. This activity including is a rice cultivation technology conducted to produce quality paddy seed at the farmer level. Research was conducted on:

1. In 2017 in the village of Tutung Bungkuk Siulak Subdistrict with an altitude of 950 meters above sea level, in March to July, varieties used by Inpari 28 Kerinci, Sarinah, Inpari 30 and Inpari 32.

2. In 2018 in Kemantan Kebalai village, Air Hangat Timur Subdistrict with a height of 800 meters above sea level in March to July, varieties used by Inpari 28 Kerinci, Sarinah, Inpari 30 and Inpari 32

3. In 2019 in the village of Bandar Sedap village, Siulak Subdistrict with a height of 850 meters above sea level in March to July, varieties used by Inpari 28 Kerinci, Sarinah, Inpari 30 and Inpari 32 


\subsection{Data collection}

Observations were made on growth data and crop yields. The resulted data were tabulated and analyzed using descriptive analysis. The processed data consists of plant height, number and length of panicle, amount of grain/panicle, amount of empty grain /panicle, the grain yield per ha, the age of plants, the rate of pest attacks and diseases.

This activity is a rice cultivation technology conducted to produce quality rice seeds at the farmer level with a 2:1 legowo jajar planting system with a planting distance of $25 \times 12.5 \times 50 \mathrm{~cm}$ conducted in farmers' fields. Fertilizers used are organic fertilizer (Petroganik $\left.2.5 \mathrm{t} \mathrm{ha}^{-1}\right)$, urea fertilizer $300 \mathrm{~kg} \mathrm{ha}^{-1}$, NPK fertilizer (15:15:15) $350 \mathrm{~kg} \mathrm{ha}^{-1}$, and pesticides (insecticide and fungicide). Were made on the data of growth and crop yields as much as 3 times replicates of each planted variety.

Data to be collected was vegetative and generative data of rice crops in the form of pest and disease attack rates as well as rice crop production, agronomic plant data. Productivity data is measured using units of tile how legowo jajar tile by choosing a uniform crop and can represent the appearance of the expanse, both in terms of growth, plant density, and the last condition in the field. Tile area, at least two sets of adjacent legowo jajar. The tile area is at least $10 \mathrm{~m} 2$ by taking the size of half the planting distance. Planting distance with legowo pattern 2:1 $(25 \times 12,5 \times 50 \mathrm{~cm})$ by taking or harvesting 4 sets of legowo plants along $5 \mathrm{~m} 2$, then the area of the plant population is $(9 \times 0.25 \mathrm{~m}) \times 4 \mathrm{~m}=11 \mathrm{~m}^{2}$ equivalent to 240 clumps. The result is weighed stated in the tile yield per kg of dry grain harvest after cleaning the tile sampling is done with three replays. In addition to the production components are also done by taking samples of plants then measured the height of the plant, the number of productive tillers, the length of panicles, the number of panicles and the harvest age.

\section{Results and discussion}

\subsection{Minimum air temperature}

Minimum air temperature (Table 1) on that usually occurs at night affects the growth of rice plants, especially in the generative phase affects production, the lowest temperature occurs in July 2018 is $17.9^{\circ} \mathrm{C}$, the average minimum temperature in 2017 is $18.06^{\circ} \mathrm{C}$ and the highest in 2018 is $19.6^{\circ} \mathrm{C}$.

Tabel 1. Minimum air data temperature during research

\begin{tabular}{crrr}
\hline Month & \multicolumn{3}{c}{ Years } \\
\hline & 2017 & 2018 & 2019 \\
March & 18.4 & 19.2 & 18.5 \\
April & 19.0 & 19.2 & 19.6 \\
May & 19.6 & 19.7 & 19.0 \\
June & 18.4 & 19.3 & 19.8 \\
July & 18.4 & 17.9 & 18.1 \\
\hline
\end{tabular}

Source [12] : https://en.tutiempo.net/climate/05-2017/ws-962070.html

\subsection{Plant height}

Figure 1 the height of plants during 2017-2019 varieties of Inpari 28 Kerinci ranges from $81.25-108.67 \mathrm{~cm}$, Inpari 30 is 85-91 cm, Inpari 32 is 90.1-91.79, Sarinah 90-92 cm, plant height is different every year of planting 


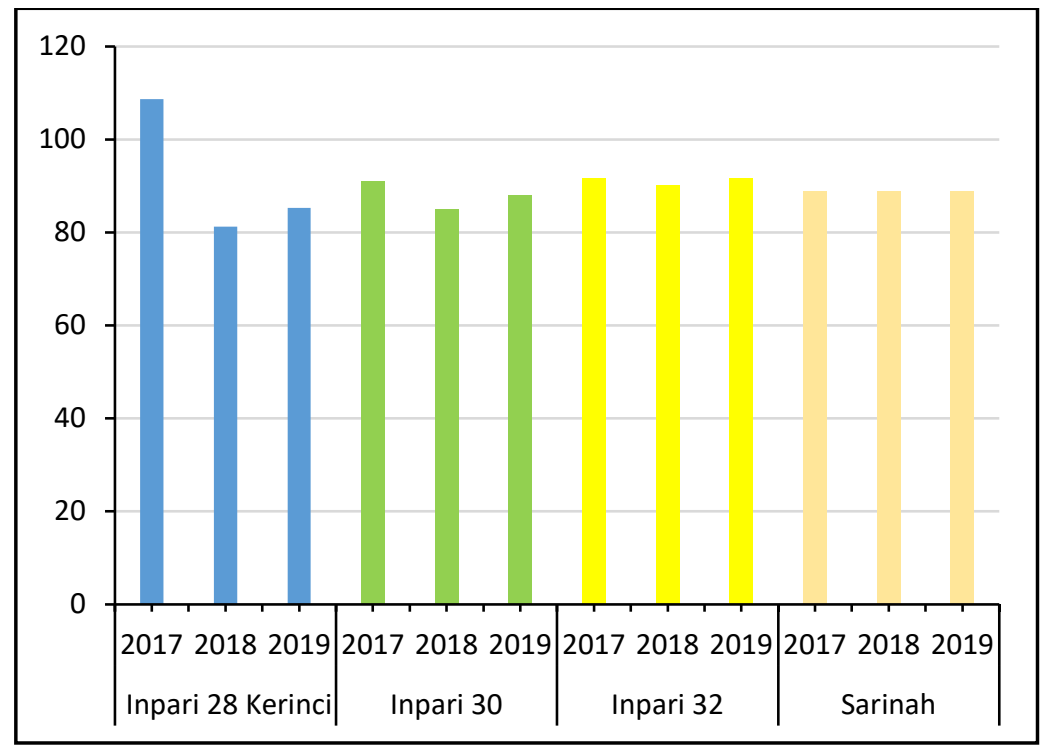

Fig. 1. Plant height $(\mathrm{cm})$

\subsection{Number of tillers}

Figure 2, data the number of tillers during 2017-2019 varieties of Inpari 28 Kerinci ranges from 19.5-20.2, Inpari 30 is $13-16$, Inpari 32 is $12-14$, Sarinah $25-27$, the average number of tillers is the most in Sarinah varieties.

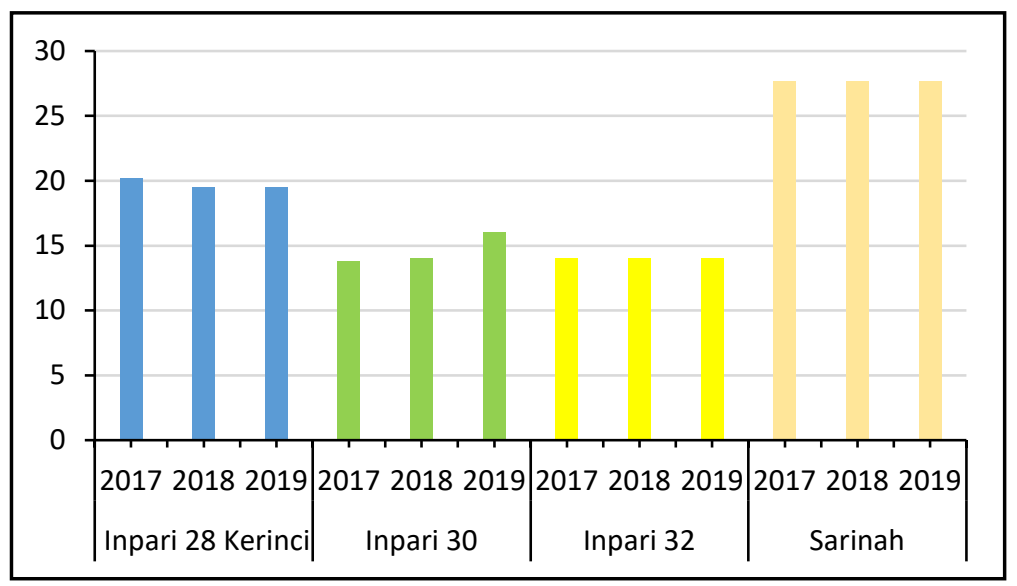

Fig. 2. Number of tillers

\subsection{Panicle length}

Figure 3 Panicle length of rice during 2017-2019 varieties of Inpari 28 Kerinci ranges from $23.33-27.71 \mathrm{~cm}$, Inpari 30 is $21.73-22.67$, Inpari 32 is $19 \mathrm{~cm}$, Sarinah is $20.95-22.83 \mathrm{~cm}$, the average panicle length of the Inpari 28 Kerinci variety is longer than other varieties 


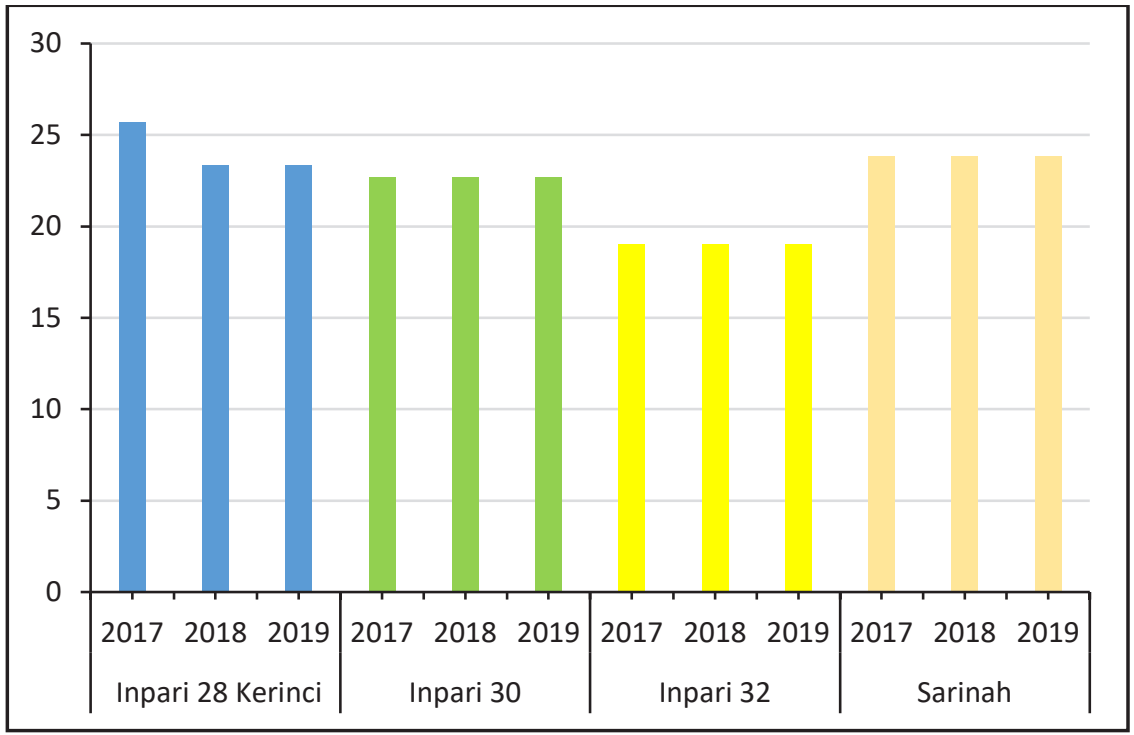

Fig. 3. Panicle length of rice

\subsection{Number of pithy grain/panicle and number of empty grain/panicles}

Figure 5 and 6, the amount of pithy/panicle grain during 2017-2019 Sarinah varieties are more followed by varieties Inpari 28 Kerinci ranges, Inpari 32 then Inpari 30. The most amount of empty grain in Sarinah varieties followed by Inpari 28 Kerinci, Inpari 32 then Inpari 30.

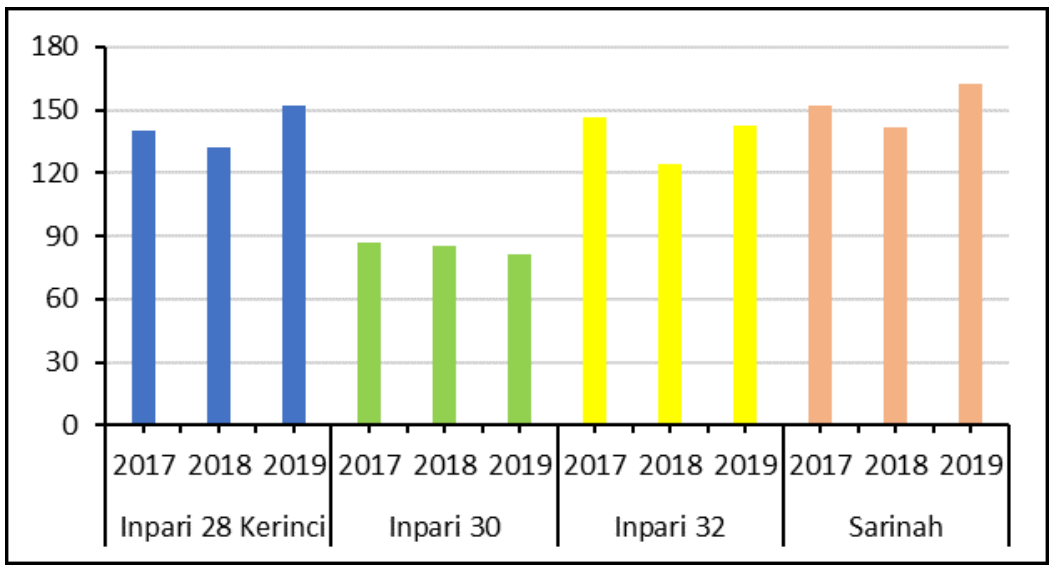

Fig. 5. Pithy grain/panicle of rice 


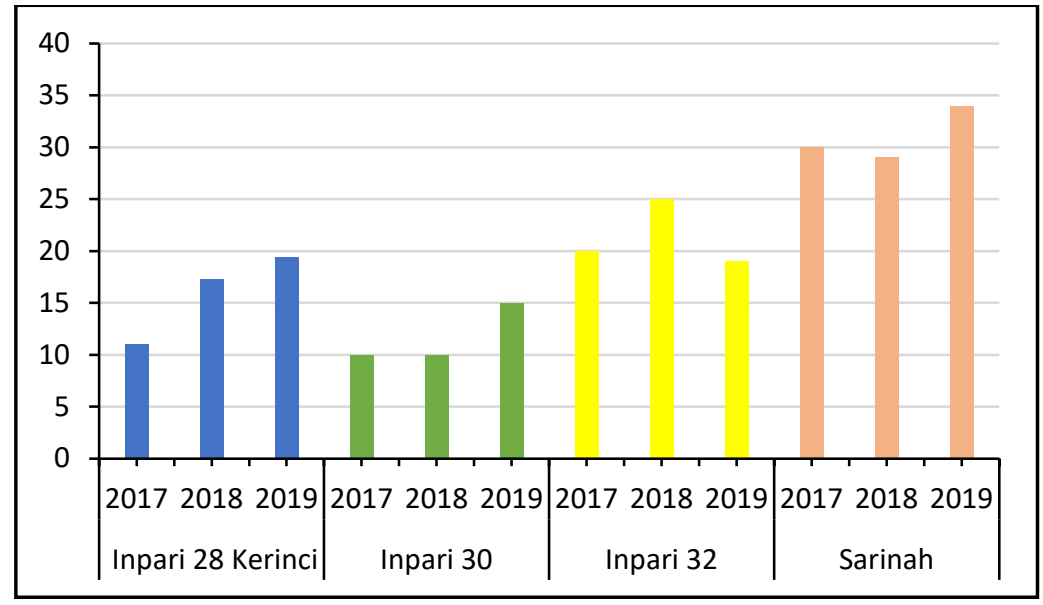

Fig. 6. Empty grain/panicle of rice

\subsection{Days to Maturity}

From figure 7, the most plant age harvest during 2017-2019 varieties of Inpari 28 Kerinci range from 96-105 days after planting, while sarinah varieties panenya age ranges from 110120 days after planting

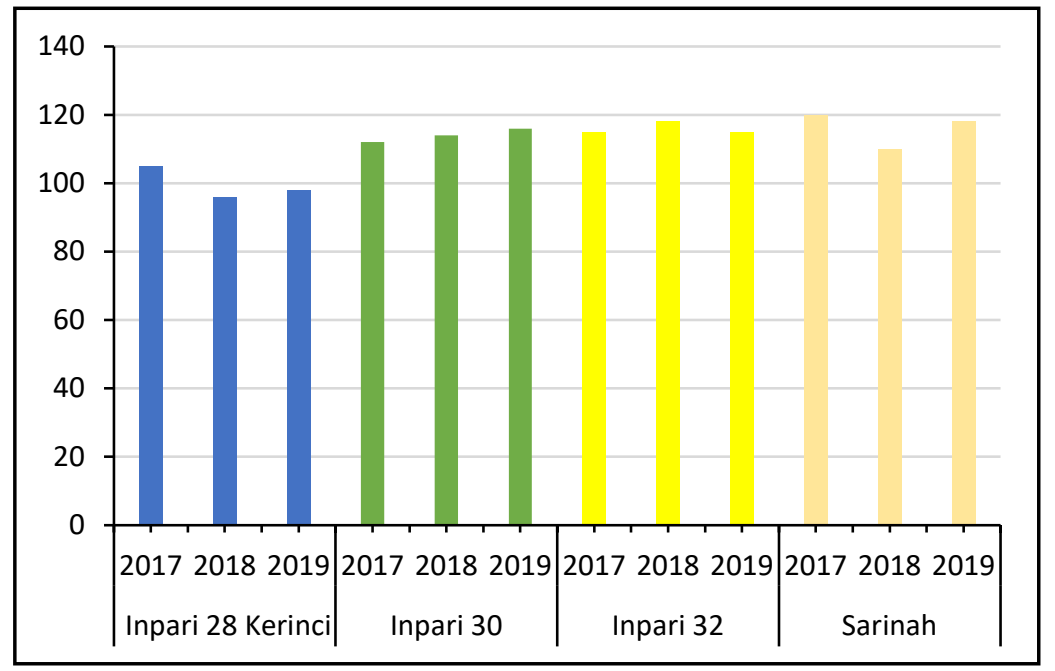

Fig. 7. Data day of maturity of rice 


\subsection{Yield}

From Fig. 8 the highest crop production achieved by Inpari 28 Kerinci Varieties in 2019 is $8.85 \mathrm{t} \mathrm{ha}^{-1}$, followed by Sarinah at $8.2 \mathrm{t} \mathrm{ha}^{-1}$. On average from 2017-2019 the highest production Inpari 28 Kerinci $7.46 \mathrm{t} \mathrm{ha}^{-1}$ followed by Sarinah 6.83 then Inpari 30 as much as $6.47 \mathrm{t} \mathrm{ha}^{-1}$ and Inpari 32 as much as $6.17 \mathrm{tha}^{-1}$.

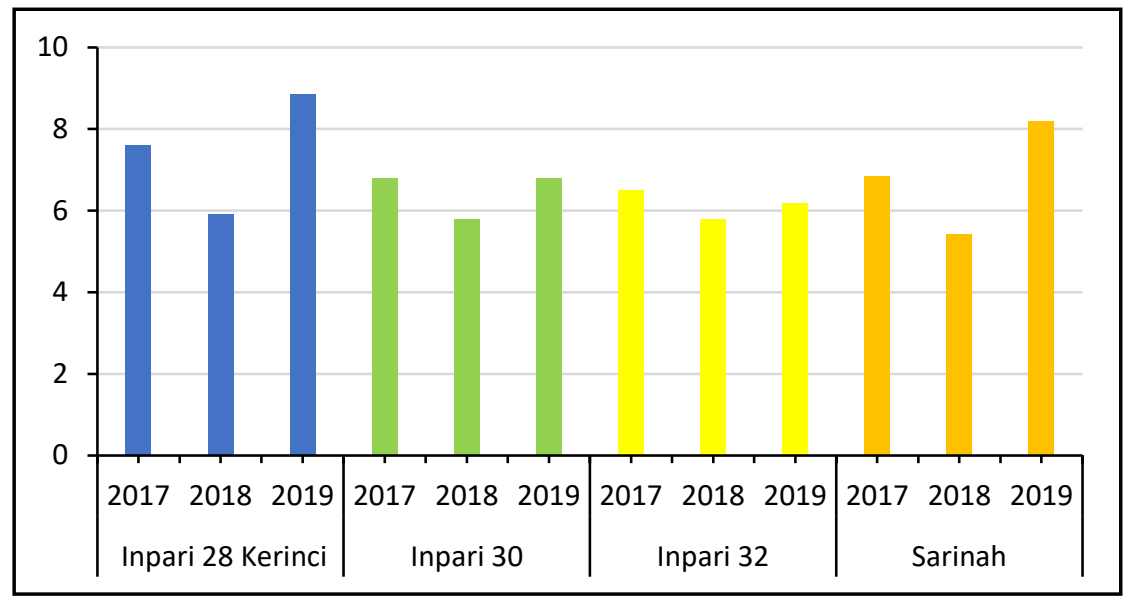

Fig. 8. Data production of rice $\left(\mathrm{t} \mathrm{ha}^{-1}\right)$

Air temperature greatly affects the vegetative and generative phases of upland rice plants, according [13], the optimal temperature for tiller growth is $18.5^{\circ} \mathrm{C}$, flowering is $18.5^{\circ} \mathrm{C}$ and maturity is $16.5^{\circ} \mathrm{C}$. Highland rice will produce well if optimal conditions are achieved during plant growth, from 2017, 2018 and 2019, the best optimal temperature conditions are achieved in rice planting in 2019 followed by 2017 and 2018 with the following average temperatures of $19^{\circ} \mathrm{C}, 18.7^{\circ} \mathrm{C}$ and $19.1^{\circ} \mathrm{C}$.

\subsection{Rate of pest and disease}

From Table 2. The rate of pest and disease attacks in the vegetative and generative phase during 2017-2019 shows no symptoms that can cause crop failure, the dominant disease in Sarinah varieties is Bacterial Leaf Blight. Inpari 32 and Inpari 30 varietie is rice whot maggot. Pest and disease attacks from observation do not cause crop failure 
Table 2. Rate of pest and disease during research in 2017, 2018 and 2019

\begin{tabular}{|c|c|c|c|c|c|c|c|c|c|c|c|c|}
\hline \multirow[t]{2}{*}{ Type pest and disease } & \multicolumn{3}{|c|}{ Inpari 28 Kerinci } & \multicolumn{3}{|c|}{ Inpari 30 } & \multicolumn{3}{|c|}{ Inpari 32} & \multicolumn{3}{|c|}{ Sarinah } \\
\hline & 2017 & 2018 & 2019 & 2017 & 2018 & 2019 & 2017 & 2018 & 2019 & 2017 & 2018 & 2019 \\
\hline Vegetative fase & & & & & & & & & & & & \\
\hline Rice whorl maggot & $5 \%$ & $<5 \%$ & $<2 \%$ & $10 \%$ & $10 \%$ & $10 \%$ & $15 \%$ & $15 \% 2$ & $<15 \%$ & $<2 \%$ & $<5 \%$ & $<5 \%$ \\
\hline Spedoftora sp & $<2 \%$ & $<1 \%$ & $<1 \%$ & $<2 \%$ & $<2 \%$ & $<2 \%$ & $<2 \%$ & $<2 \%$ & $<1 \%$ & $<1 \%$ & $<1 \%$ & $<1 \%$ \\
\hline Bacterial Leaf Blight & $<2 \%$ & $<1 \%$ & $<1 \%$ & 0 & 0 & 0 & 0 & 0 & 0 & 0 & $<1 \%$ & $<1 \%$ \\
\hline Generative fase & & & & & & & & & & & & \\
\hline Leaf blast & $<1 \%$ & $<1 \%$ & $<1 \%$ & $<1 \%$ & $<1 \%$ & $<1 \%$ & $<1 \%$ & $<1 \%$ & $<1 \%$ & $<1 \%$ & $<1 \%$ & $<1 \%$ \\
\hline Neck blast & $<1 \%$ & $<1 \%$ & $<1 \%$ & $<1 \%$ & $<1 \%$ & $<1 \%$ & $<1 \%$ & $<1 \%$ & $<1 \%$ & $<1 \%$ & $<1 \%$ & $<1 \%$ \\
\hline Bacterial Leaf Blight & $<2 \%$ & $<2 \%$ & $<2 \%$ & $<2 \%$ & $<2 \%$ & $<2 \%$ & $<2 \%$ & $<2 \%$ & $<2 \%$ & $<2 \%$ & $<5 \%$ & $<5 \%$ \\
\hline
\end{tabular}




\section{Conclusion}

Vegetative and generative growth of rice grown in the Kerinci highland (800-950 meters above sea level) was strongly influenced by the height of the place and the minimum air temperature. Inpari 28 kerinci rice varieties show good vegetative performance as well as lower levels of pest and disease attacks. Inpari 28 kerinci rice production during the three years 2017-2019 was the highest with an average of $7.46 \mathrm{t} \mathrm{ha}^{-1}$, with a harvest age of 96-105 days after transplanting

\section{References}

1. International Rice Research Institute (IRRI), IRRI Annual Report 2019 (Los Baños, Philippines, 2020).

2. N. Bandumula, Rice production in Asia: key to global food security, In Proceedings of the National Academy of Sciences, India 88, 4 (2018)

3. S. Fahad, M. Adnan, M. Noor, M. Arif, M. Alam, I.A. Khan, Y. Jamal, Major constraints for global rice production, in M. F. Mirza Hasanuzzaman, Kamrun Nahar, Jiban Krishna Biswas, (Ed.), Advances in rice research for abiotic stress tolerance (Cambridge, Woodhead Publishing, 2019)

4. V. Sridevi, and V. Chellamuthu, International Journal of Applied Research 1, 9 (2015)

5. N. Chhogyel, and Y. Bajgai, SAARC Journal of Agriculture 13, 2 (2015)

6. M. Ghimiray, Journal of Renewable Natural Resources Bhutan 8, 1 (2012)

7. I. Las, P. Wahid, Y.S. Baharsyah, dan S.N. Darwis, Tinjauan iklim dataran tinggi Indonesia, Potensi kendala dan peluang dalam mendukung pembangunan pertanian pada PJPT II, in Seminar Sehari Tentang Iklim, 6 Pebruari 1993, Padang (1993)

8. Z. Harahap, T.S. Silitonga, dan Suwarno. Pemuliaan Padi dalam PJPT II, Makalah pada Pertemuan Pemuliaan Tanaman Puslitbangtan (1993)

9. Y.L. Limbongan, B.S. Purwoko, Trikoesoemaningtyas, dan H. Aswidinnoor, J. Agron. Indonesia 37, 3 (2009)

10. Y.L. Limbongan, Analisis genetik dan seleksi genotipe unggul padi sawah (Oryza sativa L.) untuk adaptasi pada ekosistem dataran tinggi (Disertasi, Sekolah Pasca Sarjana, Institut Pertanian Bogor, 2008)

11. BPS, Kerinci dalam angka (BPS Kerinci, 2019)

12. Data climate (Depati Parbo Station, 2017)

13. S. Yoshida, Fundamentals of rice crop science (Los Baños International Rice Research, Institute, Philippines, 1981) 